\title{
Editorial for the series on gastric and gastroesophageal cancer treatment in 2020
}

This series of Annals of Translational Medicine presents a collection of review articles on the treatment of gastric and gastroesophageal cancer in 2020. The treatment of this cancer has been evolving overtime in both the locally advanced and the metastatic setting. Treatment ranges from Endoscopic resection in early stage disease and perioperative chemotherapy in locally advanced disease to combination of chemotherapy and targeted therapy in the metastatic setting.

Adenocarcinoma of the stomach and gastroesophageal junction is a common malignancy worldwide, with approximately 900,000 cases occurring annually. In the United States, although less common, this disease results in more than 10,000 death every year. The only curative treatment is surgical resection and in rare cases definitive treatment with chemotherapy and radiation. Relapse following surgery resulting in death from metastatic disease is relatively common.

Throughout the last several decades, therapies adjunctive to surgery have been extensively explored with some but not significant improvement in survival. Peri-operative treatment has been accepted as the standards of care, however, treatment still varies significantly among different geographic locations. On the other hand, and in the last several years, there have been some advances in the treatment of metastatic disease with the addition of targeted therapy as well as immune checkpoints inhibitors. Unfortunately, the prognosis is still dismal with patients rarely surviving beyond one year from diagnosis.

Therefore, this series includes in-depth reviews of several aspects of the treatment of gastric and gastrointestinal cancer such as diagnosis and treatment of Barrett esophagus and early stage disease, an update on the treatment of locally advanced and metastatic disease, the role of tumor profiling and for the first time addressing the palliative care needs in this patient population.

We are extremely grateful for the contributions of all the authors. We hope you you find these reviews to be beneficial and relevant to your practice and research and interest.

\section{Acknowledgments}

Funding: None.

\section{Footnote}

Provenance and Peer Review: This article was commissioned by the editorial office, Annals of Translational Medicine, for the series "Gastroesophageal Cancer 2020". The article did not undergo external peer review.

Conflicts of Interest: The author has completed the ICMJE uniform disclosure form (available at http://dx.doi.org/10.21037/ atm-2020-gc-09). The series "Gastroesophageal Cancer 2020" was commissioned by the editorial office without any funding or sponsorship. KA served as the unpaid Guest Editor of the series and serves as an unpaid editorial board member of Annals of Translational Medicine from Nov 2019 to Oct 2021.

Ethical Statement: The author is accountable for all aspects of the work in ensuring that questions related to the accuracy or integrity of any part of the work are appropriately investigated and resolved.

Open Access Statement: This is an Open Access article distributed in accordance with the Creative Commons AttributionNonCommercial-NoDerivs 4.0 International License (CC BY-NC-ND 4.0), which permits the non-commercial replication and distribution of the article with the strict proviso that no changes or edits are made and the original work is properly cited (including links to both the formal publication through the relevant DOI and the license). See: https://creativecommons.org/ licenses/by-nc-nd/4.0/. 


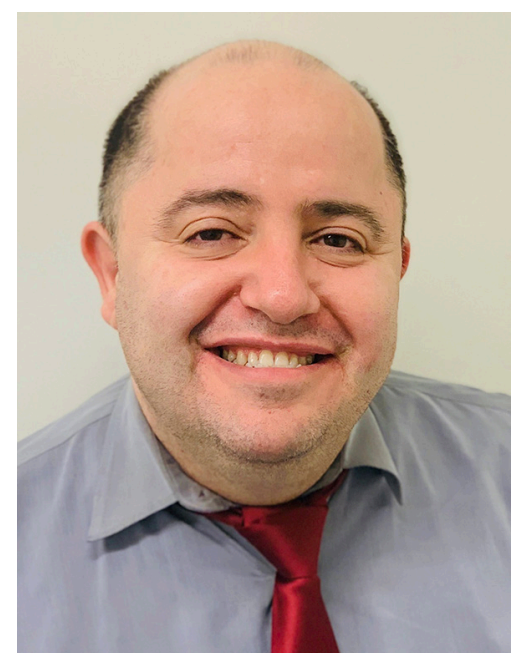

Khaldoun Almhanna

Khaldoun Almhanna, MD, MPH Associate Professor of Medicine, The Warren Alpert Medical School of Brown University, Lifespan Cancer Institute. Gastrointestinal Oncology, Rhode Island Hospital, Providence, RI, USA. (Email: Kalmbanna@Lifespan.org)

Submitted Aug 01, 2020. Accepted for publication Aug 26, 2020. doi: $10.21037 / \mathrm{atm}-2020$-gc-09

View this article at: http://dx.doi.org/10.21037/atm-2020-gc-09

Cite this article as: Almhanna K. Editorial for the series on gastric and gastroesophageal cancer treatment in 2020. Ann Transl Med 2020;8(17):1102. doi: 10.21037/atm-2020-gc-09 